\title{
Empowering Social Workers to Transform the Dominant Narrative: Advocating for Human Rights over Corporate Profit
}

\author{
Robin Ann DeLuca-Acconi ${ }^{1}$
}

Published online: 19 December 2016

(C) Springer International Publishing 2016

\begin{abstract}
Social workers can play an essential role in creating global systemic changes that lead to respect for human rights. For this to take place, social workers need to question and critique current policies and propose alternatives. This is a longitudinal case study (2001-2015) of the campaign to eradicate child labor and human rights infractions from the cocoa industry in the West Africa countries of Côte d'Ivoire and Ghana. The movement to transform the labor practices of the cocoa industry offers a unique insight into the process of a human rights campaign. This study uses the campaign to inform social workers about incorporating effective discursive strategies into a movement's message. It focuses on the manner in which activists questioned the policies of the cocoa companies and presented alternative methods of doing business. Narratives are created in order to alter public beliefs about the problem in a manner that is in line with stakeholder goals. This process of debating and framing issues in the public sphere results in the social construction of problems and reality (Dahan and Gittens in Journal of Business Ethics, 92, 227-249. doi:10.1007/s10551-009-0151-8, 2010). There is "no reality apart from social meanings;" metaphors and stories provide this meaning (Stone, 2011, p. 378). The stakeholders in the cocoa campaign created strategic and competing narratives, designed to garner support for their policies from policy makers. Qualitative framing analysis was employed to
\end{abstract}

Electronic supplementary material The online version of this article (doi:10.1007/s41134-016-0025-9) contains supplementary material, which is available to authorized users.

Robin Ann DeLuca-Acconi

rdelacconi@gmail.com; robin.deluca@ stonybrook.edu

1 Stony Brook University School of Social Welfare, Health Sciences Center, Level 2, Stony Brook, NY 11794-8231, USA explore the stakeholders' discourse and competing narratives surrounding both the causes of, and solutions to, the Worst Forms of Child Labor (WFCL). Press releases from human rights activists and the cocoa industry were analyzed in order to recount the debate's history. Findings illustrate that strong resonant frames led to positive changes in the cocoa industry. Stakeholders ultimately transcended the conflict caused by contrasting ideological differences and created policies that indicated a respect for human rights. These policies included using Fair Trade certification, creating supply chain transparency, removing workplace hazards, increasing access to schooling and vocational training, improving the quality of education, and empowering women farmers. These results highlight that activists' suggestions were incorporated into U.S. government protocols and the cocoa industry's corporate social responsibility (CSR) reports. Policy implications include empowering social workers to advocate for policies that support those most at need, craft frames so that they resonate with the public and policy makers, create alternative policies to the present neoliberal reality, and hold corporations and governments accountable to human rights treaties and conventions. Social workers are encouraged to challenge mindsets that are embedded in a domination mentality and create alternative policies that elevate human rights.

Keywords Human rights · Social work advocacy · Framing · Corporate social responsibility $\cdot$ Child labor

\section{Social Work and Human Rights}

Some scholars have argued that human rights are "one of the rare moral precepts whose normativity is self-evident... allowing them to be carried across borders would make for a better world, one that is more attentive to human rights and to 
other moral causes" (Etzioni 2010, p. 187). One cornerstone of the social work profession's mission is to advocate for practices and policies that create conditions that respect human rights in order to create this "better world." The goals of social work are intertwined with the premise that the realization of universal human rights is essential to a just and ordered society. Social work can better realize its goals by integrating human rights principles into practice and policy (Reichert 2011, p. 217).

According to the Committee on Social Work Education's (CSWE 2008) Educational Policy and Accreditation Standards (1.2 Achievement of Purposes), two objectives of social work education include "preparing social workers to alleviate poverty, oppression, and other forms of social injustice and preparing social workers to recognize the global context of social work practice" (p. 5). The global context of social work includes taking a critical view of current international policies. According to the International Federation of Social Workers' (IFSW) Statement of Principles (4.2.4 Social Justice), "Social workers have a duty to bring to the attention of their employers, policy makers, politicians and the general public situations where resources are inadequate or where distribution of resources, policies and practices are oppressive, unfair or harmful" (p. 2). In 1994, the United Nations released a document "Human rights and social work: A manual for schools of social work and the social work profession." In that document, it quoted the IFSW, stressing "social work from its inception has been a human rights profession" (p.13). It is essential for social workers to look to human rights documents, treaties, and conventions that emanate from the United Nations for guiding principles for their practice.

In 2012, the IFSW, the International Association of Schools of Social Work (IASSW), and the International Council on Social Welfare (ICSW) released the "Global Agenda: Social Work and Social Development." This document stresses the need for social workers to use a human rights framework for practice, especially in our interconnected global economy.

Social workers can be vital to envisioning a just and equitable world and can be the architects laying the groundwork of that world's creation.

\section{Social Workers Questioning the Status Quo; Reframing the Future for Human Rights}

Social workers have often "critiqued economic globalization and written about the impacts of neoliberal ideologies on social welfare extensively, yet there has been little in the U.S. literature focusing on liberation practice interventions such as that engaged in by global economic justice activists" (Pyles 2009 , p. 85). Social workers can lead the discussion about inequality and human rights infractions caused by globalization practices. They can learn to frame their positions in a manner that leads to policy rooted in human rights and social justice.

Pyles (2009) pointed out that framing is "arguably one of the most important skills" for social workers so that they may "critically reframe disempowering media messages and false assumptions about institutions and economic policies" (p. 85).

\section{Expressing Ideology in the Frame}

Social workers who are a part of a social movement frame an issue, use ideology as their basis. The framing of that ideology becomes a cornerstone of the movement's identity and "thus collective action frames are action-oriented sets of beliefs and meanings that inspire and legitimate the activities of the social movement organization" (Snow and Benford 2005, p. 614). Ideology can be considered a social construct, and framing is the mechanism used to persuade stakeholders to believe in a collective action movement's truth (Gillan 2008).

Social workers are often involved in human rights campaigns that produce a message that is outside prevailing ideology. That prevailing ideology is frequently based in the hegemonic belief system of the era, reinforced by those in power. There is often an inherent tension between the ideological beliefs of social workers and those in power. In the case of the cocoa industry, it is the tension between a neoliberal ideology that guide free-trade agreements and regulation of business that ensures respect for human rights.

Hegemony can be considered the ideology put into practice by the elites; these beliefs permeate our institutions and power relations continue to be reproduced (Maney et al. 2005, p. 6). Frames can serve as a contrasting device to hegemony, reinterpreting the world "to mobilize potential adherents and constituents to garner bystander support and to demobilize antagonists" (Snow and Benford 1988, p. 198). Social workers can present a frame that is counter to hegemony, which are "developed and proffered as an antidote" (Snow and Benford 2005, p. 209). When social workers attempt to challenge dominant hegemony, the frames created aim at a transformation of belief systems that lead to policy change (Abramovitz 2010, p 229).

\section{Components of Collective Action Framing-an Overview for Social Workers}

Defining the problem at hand is the first important step when attempting to remedy a societal ill. Stone (2011) found that problem definition is a strategic use of narrative, because stakeholders "deliberately and consciously fashion portrayals so as to promote their favored course of action" (p.133). There are three types of framing that occur in collective actions. The first is known as diagnostic framing. The way stakeholders 
diagnose an issue is significant; it will cause them to concentrate on one "aspect of the problem, and not others" and to point to "certain individuals or groups as responsible for the problem, and thus identify those responsible for change" (Coburn 2006 p. 347).

Prognostic framing is the next core task for a social movement when creating a collective action frame (Snow and Benford 1988). Prognostic frames result when stakeholders offer solutions to societal problems that are consistent with the way they have been diagnostically framed. Prognostic framing is involved with recommendations for resolution to societal problems (Sandberg 2006).

The last element of collective action framing is motivational framing. In this last framing task, advocacy groups attempt to provide the motivation and supply a "call to arms" needed to engage in "ameliorative collection action, including the construction of appropriate vocabularies of motive" (Benford and Snow 2000, p. 617). Activists should "connect and align" both the prognostic and diagnostic frame into a coherent action plan when constructing a motivational frame (Barnett 2005).

Frame Resonance Benford and Snow (2000) point out that it is essential that a frame resonate with the intended audience and identified aspects of resonance. Empirical credibility is strong when a frame uses empirical evidence from a credible source. Experiential commensurability is the extent to which a frame will resonant with the everyday experience of an audience. Narrative fidelity is the extent to which the frame is significant to the prevailing cultural ideology (p. 622).

Maney et al. (2005) found that policy makers need to craft frames that resonant highly with the public to pass new policy initiatives. Maney et al. (2005) developed a typology that included the aforementioned dimensions of resonance from Benford and Snow (2000), as well as four new dimensions of identity appeal, moral authority, emotional consonance, and threat salience. Identity appeal is the degree to which a frame activates the "collective identities held by potential supporters" ( $p$.3). Moral authority is concerned with a frame's ability to connect its claims to a sense of ethical superiority. The emotional consonance of a frame uses stakeholders' emotions to increase support for policy proposals. Threat salience elicits fear in an effort to obtain support for the frame (p. 3).

Maney et al. (2005) also identified three ways that activists use hegemony to create a resonant frame: to harness, strengthen, or challenge hegemony. Power holders use frames to strengthen hegemony, which leads to policy prescriptions that maintain and strengthen the status quo. In contrast, those who challenge hegemony "attempt to limit the resonance of proestablishment framing by casting aspersions upon the dominant symbolic repertoire" (p. 7). When challenging hegemony, activists may experience ridicule from those who reject what may seem a radical idea. Instead, some human rights organizations may choose to harness hegemony. Activists may "use ideas from the dominant symbolic repertoire to support their oppositional claims" (p. 7). Activists may use a "hybrid" of both harnessing and challenging hegemony in order to increase the resonance of the frame.

\section{Study Overview}

This study expands on the work by Dahan and Gittens (2010) entitled Business and the Public Affairs of Slavery: A Discursive Approach of an Ethical Public Issue. Dahan and Gittens' work centered on the ethical dimension of public issues, highlighting the framing and counter framing practices in the cocoa industry and human rights activists. It expands Dahan and Gittens (2010) work by not only examining stakeholder's frames, but exploring the relationship between framing and hegemony, focusing on frame resonance and investigating the link to policy enactment and discussing implications for social work and human rights.

\section{Human Rights Infractions in the Cocoa Industry}

In September of 2000, the BBC's Channel 4 broadcasts a documentary about slavery on cocoa plantations located in the Western African nations of Ghana and Côte d'Ivoire. The documentary entitled Slavery: A Global Investigation brought the issue of child slavery to the forefront of the media's attention (Grossman-Greene and Bayer 2009). The documentary was a catalyst for the modern human rights movement designed to eradicate forced and child labor in the cocoa industry (Dahan and Gittens 2010).

In January 2001, U.S. Representative Eliot Engel (D-N.Y.) and Senator Tom Harkin (D-Iowa) responded to mounting public pressure following the media blitz of the documentary by adding a rider to the 2001 agriculture bill, HR 2330, the Agriculture, Rural Development and Food and Drug Administration Appropriations, FY2002 (HR 2330, 107th Congress, 2001). The amendment allocated money to the Food and Drug Administration to develop a "slave free" label for chocolate products (H.Amdt. 142, HR 2330, 107th Congress, 2001). The final bill, as amended, passed the House of Representatives July 11, 2001 (HR 2330, 107th Congress, 2001).

In the summer of 2001, the amendment to HR 2330 that would impose the "slave free" label on chocolate came under review in the Senate (Engel 2001). The Chocolate Manufacturers Association (CMA) responded by hiring former senators Bob Dole (R-KS) and George Mitchell (D-ME) to lobby Congress to omit the rider (Off 2006; Dahan and Gittens 2010). The intense lobbying was effective. By the time the bill reached the Senate on October 25, 2001, Congressman 
Engel's amendment had been removed (HR 2330, 107th Congress, 2001).

Simultaneously, Sumana Chatterjee and Sudarsan Raghavan traveled to West Africa as investigative reporters for Knight Ridder Newspapers. On June 24, 2001, they published a series of articles entitled A Taste of Slavery that documented child slavery in the cocoa fields. What ensued next was a public controversy over whether child slavery even existed in the cocoa fields, with the cocoa industry claiming that the reports were not true or exaggerated (Off 2006). Public outcry continued to grow, and the human rights organizations intensified the campaign to change the labor practices of the cocoa industry (Dahan and Gittens 2010).

The pressure resulted in a compromise among major stakeholders. In place of legislation mandating the "slave free" label, Congress, the Cocoa Manufacturing Association (CMA), and the World Cocoa Foundation (WCF), along with representatives from NGOs, the cocoa industry, human rights organizations and trade unions, came to a voluntary agreement on September 19, 2001 (Harkin-Engel Protocol 2001). The cocoa companies that signed the agreement included Guittard Chocolate Company, M\&M/ Mars, World's Finest, Archer Daniels Midland, Nestlé, Blommer, Hershey, and Barry Callebaut AG.

Entitled Protocol for the Growing and Processing of Cocoa Beans and their Derivative Products in a Manner that Complies with the ILO Convention 182 Concerning the Prohibition and Immediate Action for the Elimination of the Worst Forms of Child Labor (WFCL), the document is more commonly referred to as the Harkin-Engel Protocol or simply the Protocol.

Harkin and Engel set out to make change to legislation on a U.S. agricultural bill. Through intensified advocacy and negotiation, it evolved into an international voluntary agreement. The international cocoa industry and global government leaders agreed to concentrate on eliminating the Worst Forms of Child Labor, as defined by the ILO. The Protocol attempted to do so by ensuring that each stakeholder is responsible for creating an infrastructure that would lead to the elimination of the WFCL.

The Protocol outlined six objectives in order to achieve this goal: publishing a public statement of need for and terms of an action plan; the formation of multi-sectoral advisory groups; a signed joint statement on child labor to be witnessed at the ILO; memorandum of cooperation; the establishment of a joint foundation; and a creation of credible certification standards to ensure cocoa was not harvested with WFCL (Harkin-Engel Protocol, 2001).

\section{Human Rights Conventions and the Protocol}

The Protocol was voluntary and was based on the International Labor Organization's (ILO) Conventions 29,
105, and 182 The ILO is an agency of the United Nations that oversees "international labor standards...that brings together representatives of governments, employers, and workers to jointly shape policies and programs promoting decent work for all" (ILO n.d.).

ILO Convention 29, Forced Labor Convention, provides the definition of forced labor as "all work or service which is exacted from any person under the menace of any penalty and for which the said person has not offered himself voluntarily" (ILO, n.d.a). ILO Convention 105, Abolition of Forced Labour Convention prohibits the use of forced and bonded labor (ILO, n.d.b). The government of the Côte d'Ivoire signed onto Convention 29 in 1960 and Convention 105 in 1961, while Ghana signed onto both these Conventions in 1957 (United Nations, n.d.a), ostensibly prohibiting forced or compulsory labor in both countries. The USA signed Co105 in 1991, but never ratified Co29.

The ILO Convention 182, Convention Concerning the Prohibition and Immediate Action for the Elimination of the Worst Forms of Child Labour, uses the above definitions. In addition, it and defines the WFCL as "all forms of slavery or practices similar to slavery such as the sale and trafficking of children...the use, procuring or offering of a child for prostitution... offering of a child for illicit activities...work which by its nature or the circumstance in which it is carried out is likely to harm the health, safety or morals of children." (Payson Center, 2009 Appendix 9). The Government of Ghana signed in 2000, the Côte d'Ivoire signed in 2003, and the USA signed in 1999 (United Nations, n.d.a.).

Both the BBC documentary and A Taste of Slavery documented forced labor practices and WFCL in violation of ILO Conventions 29, 105, and 182. These conventions are the cornerstone of the Protocol, but the slavery and abuse on the cocoa fields were in violation of other documents including the "Universal Declaration of Human Rights."

The UDHR codified the concept of the universality of human rights into an international comprehensive document (Risse et al. 1999). The UDHR lead to the creation of an international legal system: the International Covenant on Civil and Political Rights (ICCPR) and the International Covenant on Economic, Social and Cultural Rights (ICESCR) (Risse et al. 1999). The human rights infractions that were discovered on the cocoa fields were in direct violation of many articles of the UDHR, first and foremost Article 1; workers were stripped of human dignity on the cocoa fields. In addition, but not limited to, workers were denied their "economic, social and cultural" rights, as outlined in Articles 22-27 (Wronka 2017, p. 23). Slavery on the fields is against Article 5 of the ICCPR, which prohibits the "slave trade in all its forms and forced or compulsory labor" (Wronka 2017, p. 78). The children in the cocoa fields were denied access to education in 
violation of Articles 2 and 13 of the ICESCR which prohibits the "economic and social exploitation of children" and acknowledges the right to education (Wronka 2017, p. 84). The ICCPR and the ICESCR were both ratified by Cote d'Ivore in 1992 and by Ghana in 2000. The USA signed but never ratified the ICESCR and ratified the ICCPR in 1992.

The United Nations' 1989 Convention on the Rights of the Child (CRC) first recognized and documented children's rights as a separate subset of human rights. Ghana was the first country to ratify the CRC on February 51990 and Côte d'Ivoire ratified it in February of 1991. The USA has never ratified the CRC. The practices in the cocoa fields of West Africa were in violation of almost every article the CRC, putting at risk the "standard of living adequate for the child's physical, mental, spiritual, moral, and social development" (United Nations, n.d.b).

After the Protocol passed, the debate continued over who was responsible to uphold these agreements and protect the rights of the children on the cocoa farms in West Africa. Both sides used the fact that Ghana and the Côte d'Ivoire signed onto human rights treaties in the campaign. The cocoa industry claimed that it was both countries' responsibility to ensure they abided by human rights conventions and treaties. The activists claimed that the neoliberal reforms forced upon Western Africa rendered compliance impossible as farmers had to turn to forced and child labor.

The root causes of child slavery and as well as who was responsible for the conditions were at the heart of the debate. Various policies were passed, including corporate social responsibility policies and an update to the original Protocol. The Framework of Action to Support Implementation of the Harkin-Engel Protocol was released in 2010. The Framework "categorically reaffirms the need to implement the Harkin-Engel Protocol;" however, the notable difference "is that while the 2001 Harkin-Engel Protocol sought to eliminate WFCL by 2005, the 2010 Joint Declaration seeks to reduce WFCL by $70 \%$ by 2020 " (10 Campaign 2011, p. 11).

\section{Methodology}

A search on $P R$ Newswire resulted in 196 press releases from human rights organizations. The websites of these human rights organizations were examined to further ascertain themes and frames. One hundred thirty-four documents including press releases, statements, and interviews from the cocoa industry and the eight cocoa companies that signed onto the Protocol were retrieved. The websites of the cocoa companies were studied as well. Seventy-two media accounts were obtained from Lexis/Nexis Database. There were 18 official statements from Senator Harkin and Congressman
Engel on their websites; five congressional hearings and reports were on Congress.gov.; three statements from the United States Department of Labor and U.S. Agency for International Development website; and three reports from the official site of Payson Center for International Development and Technology Transfer at Tulane University.

NVIVO was utilized as it has been shown to be successful in framing analysis and in the ability to code a large number of documents (Maney et al. 2005).

The documents were divided into the human rights activists and the cocoa industry. Frame resonance and the relationship to hegemony were then investigated. The underlying ideological positions of each stakeholder were examined. Policy recommendations from each stakeholder were documented.

\section{Results}

\section{Uncovering the Frames in the Campaign for Human Rights in the Cocoa Industry}

One initial finding was there was a network of human rights organizations that utilized the Fair Trade frame, consistent with the findings of Dahan and Gittens (2010). However, after further investigation, it became evident that there were three separate groups of organizations. These organizations were guided by overlapping ideology that occurred in a spectrum from critical organizations to those that were progressive but less critical in their policy recommendations. These organizations were guided by varied worldviews and supported diverse interventions for WFCL. Depending on where the organization fell on the spectrum impacted the diagnostic and prognostic component of the frame and influenced policy recommendations. This is consistent with findings of Parkhurst (2012), who found that the ideological basis for a frame impacts the manner in which evidence is presented during policy formation.

The groups are referred to as the Critical Network, Fair Trade Network and Protocol Network. Figure 1 illustrates the network of activists with three organizations that led each network. These organizations were identified as lead organizations as they released the most statements in their prospective group.

The organizations that signed the Protocol, the Protocol Network can be said to harness hegemony, as they looked to enhance "the resonance and potency of their framing among those with worldviews rooted in the dominant culture" (Maney et al. 2005 p. 2). The worldview of this organization included support of voluntary industry regulation. This network used the cocoa industry as an exemplar. According to Kevin Bales from Free the Slaves, "If other industries acted with such social and moral responsibility, we would be much nearer to freedom for the 27 million bonded worldwide" (Off 2006). They cited the collaborative nature of the Protocol as an 
Fig. 1 Network of activists

Critical

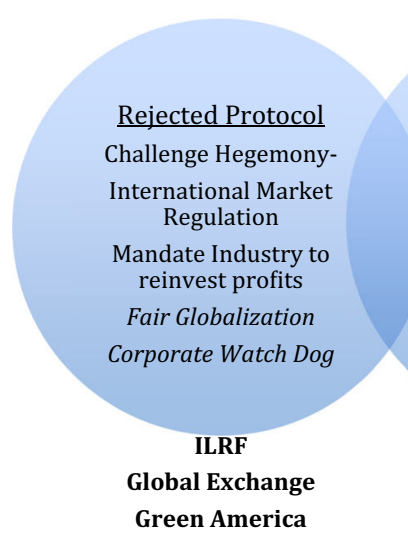

Green America
FairTrade

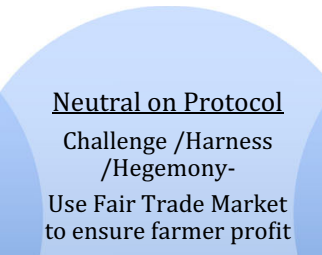

Fair Trade

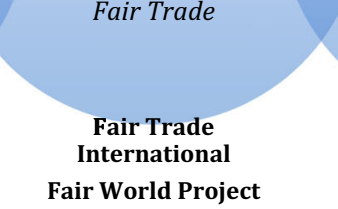

Fair World Project
Protocol

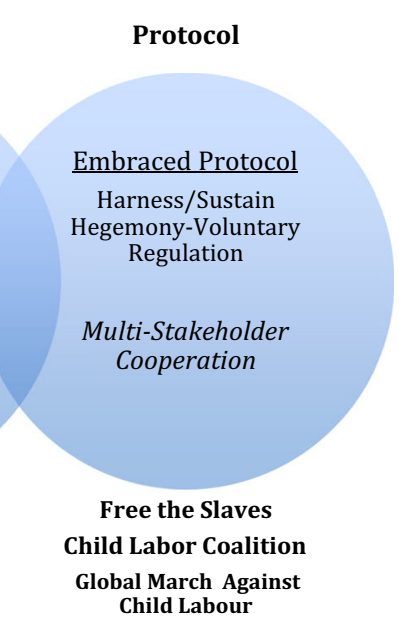

example of an exemplary practice to rectify WFCL (see Free the Slaves n.d).

The Protocol Network includes the group of organizations that signed onto the Protocol and is most closely aligned with the industry. They did not engage in diagnostic framing at this time, offering the Protocol as a way to collaborate and discover what is most needed in the cocoa industry. The Protocol Network's frame is labeled as the Multi-Stakeholder Collaboration, as its messages often include the importance of all parties working together.

Other human rights organizations called for regulations well beyond the Protocol. These organizations challenged neoliberal hegemony and globalization policies. The International Labor Rights Forum (ILRF) led the group that looked to challenge hegemony. The ILRF was one of the first organizations to publicly criticize the Protocol. They released a statement entitled "Statement on Industry Protocol Regarding the Use of Child Labor in West African Cocoa Farms" in which they engaged in diagnostic framing by maintaining that forced child labor was the result of the unfair compensation to farmers: "The industry-led initiative fails to call for concrete steps to ensure that farmers are getting a fair price for their product, which significantly impacts the use of child labor" (International Labor Rights Forum, 2002 para 2).

The group lead by the ILRF was labeled the "Critical Network," as this group takes a critical position on globalization policies, with the ideological basis of state and global regulation. The Critical network challenged prevailing hegemony in the cocoa industry that neoliberal theory should serve as the basis for trade policy. They framed the issue in way that highlights the exploitive relationship not only between the cocoa farmers and the cocoa manufacturers but between the Global North and Global South. The Critical Network's diagnostic frame includes inequitable trade laws; "International trade agreements anchored by the U.S. cement a model of development for countries in the Global South that favors wealthy elite over workers who lack access to capital" (ILRF, n.d.).
The frame of the Critical Network is labeled as Fair Globalization. The ILRF framed the problem of WFCL in critical terms when they published "The World Bank and IMF Policies in Côte d'Ivoire: Impact on Child Labor in the Cocoa Industry." In this 2004 document, the ILRF traced the consequences of IMF involvement in the Côte d'Ivoire beginning in 1989. ILRF highlighted that Côte d'Ivoire entered into six World Bank loans from 1989 to 1993 and an Enhanced Structural Adjustment Facility (ESAF) loan in 1994. As a result of entering into the ESAF loan, Côte d'Ivoire had to reduce government expenditures and increase privatization. According to the ILRF (2004), this liberalization of the cocoa sector resulted in "high economic instability, increased agriculture poverty, and widespread child labor practices." (p. 2). The consequences of reducing governmental expenditures were a decline in the quality of education of the national health system. Currency devaluation resulted in a decreased standard of living and purchasing power of the poor, as well as an increased debt burden (p. 2). The ILRF (2004) concluded that "liberalization of the cocoa industry, a key commodity sector, produced disastrous results at a time when world commodity prices were falling.... These ill-advised policies have altogether fueled the abusive practice of child labor on cocoa farms" (p. 8).

Oxfam senior advisor Max Lawson added to the criticism of neoliberal policies when he stated, "The IMF is too brutal...demanding balanced books within one or two years. The only way to make such a deep cut is in social spending" (Toynbee 2009 para 10). Global Exchange, a part of the Critical network, added to the literature that diagnosed the problem of WFCL as emanating from international neoliberal policy: "Before its involvement with the IMF and World Bank, the Ivory Coast operated a Stabilization Fund... that set export prices for the crop year and guaranteed producers a stable income" (Toler and Schweisguth 2003).

At this point, a third group of activists were identified in the data. This group is a diverse collection of organizations that diagnostically framed the cause of WFCL as low prices for farmers 
but did not challenge neoliberal globalization practices. This group criticized the Protocol for not addressing poor compensation as the root cause of poverty in the cocoa industry. The third category of activists is referred to as the "Fair Trade Network" and their frame is Fair Trade. Media articles and press releases included headlines such as "Farmers need higher cocoa prices" (Dadson 2001) and "The bondage of poverty that produces chocolate" (Onishi 2001). Most media articles fell into this category. At this time, movement organizers linked such diverse organizations as American Postal Workers Union, Guatemala Human Rights Commission USA, West Africa Rainforest Network, and Youth for Environmental Sanity (YES). This provides an example of frame bridging, which occurs when varied organizations come together and frame an issue in the same manner (Benford and Snow 2000).

At this point, a prognostic frame was introduced. The Critical Network alongside the Fair Trade Network proposed the Fair Trade system as a solution that could be utilized to curb the use of child labor. Global Exchange authored a letter to M\&M Mars, alongside 222 varied organizations (see Global Exchange 2002). The letter critiqued the Protocol and diagnostically framed the problem of WFCL as the result of low cocoa prices and low compensation to farmers and a prognostic frame of fair compensation: "[The Protocol] is a positive development. However, it does nothing to correct the low world cocoa prices that are a root cause of slave labor practices. Solutions to the current crisis must include ensuring that farmers are paid a fair price for their harvest" (Toler and Schweisguth 2003).

\section{The Frames of the Cocoa Industry}

The industry's initial reaction to the reports of child and slave labor was to downplay the extent of the problem and deny the reports from the BBC and Knight Ridder papers. A press release from the Biscuit, Cake, Chocolate and Confectionery Alliance (BCCCA) stated "We do not believe that the farms visited by the programme are in the least representative of cocoa farming in the Ivory Coast, although the claims cannot be ignored" (BBC 2001). According to Larry Graham, president of both the National Confectioners Association and the Chocolate Manufacturers Association of Vienna; "Everyone we have talked to in the country who has worked there years and years has never seen this practice" (Chatterjee and Raghavan 2001, para. 14). Nestlé stated "We are confident that while illegal practices may exist they are limited in scale and confined to particular areas" (Jeffery and Stafford 2001, para. 2). Mars declared that any forced labor in cocoa production in the Côte D'Ivoire "was probably only in isolated pockets" (Jeffery and Stafford 2001, para. 3).

The pressure from the human rights activists led to eventual changes in the cocoa industry. The cocoa industry's reaction went from denial of the problem to eventual acceptance of human rights as a corporate norm. The cocoa industry's frames included the collaborative, responsible cocoa as well as the sustainability frame. They highlighted their participation in the Protocol as evidence of collaboration.

Hershey and Nestlé both invoked the collaborative frame. Hershey claimed the success of the Protocol was due to "the involvement of communities, farmer organizations, industry and governments" (CNN Freedom Project 2012). They stressed that "no single entity or initiative can solve this problem;" Nestlé maintained that they "are committed to do the hard work with governments and industry partners to achieve a permanent solution" (Nestlé 2010).

While using the collaborative and responsible cocoa frames, the industry utilized hope to increase the resonance of its frames. The industry released a statement that the 2010 Framework would "improve the lives of cocoa farming communities in Côte d'Ivoire and Ghana" (NCA 2012). The industry continued to frame itself in a positive light and engender positive emotions toward cocoa companies, thus increasing the resonance of the responsible cocoa frame. In addition, the companies pointed out the ways their commitment to the Framework would improve their dedication. The National Confectionary Association (2012) emphasized programs that have "already made a difference to over a million vulnerable children in West Africa...[These] programs focus on increasing access to education (building schools, training teachers)" (para. 2).

Over time, there began to be change in the cocoa industry. Nestlé released a statement that "given the extent of child labor in the Ivory Coast, it is inevitable that farms supplying Nestle used child labor" (Nieburg 2011, para. 7). Nestlé announced its plan to purchase enough certified Nestlé Cocoa Plan beans to produce the entire line of everyday crunch bars (Nestlé 2010). Mars proclaimed that it had met the " 2011 goal of purchasing $10 \%$ of its total cocoa supply as certified sustainable, and in 2012, it will exceed its original target of 20\%" (Mars 2012).

Certifications that respected labor standards began to increase by the end 2012. Nestlé committed to utilizing Fair Trade as a certification for some of their chocolate bars and UTZ certification for the remainder of their product lines. Mars also began to use Fairtrade International "to include important labor and productivity standards" (Mars 2012). Hershey released the statement that it would be "on track to source at least $10 \%$ of its total global cocoa purchases from certified sources in 2013, the first year of its 2020 commitment. They also announced benchmarks for reaching $100 \%$ by 2020" (Hershey 2013). In fact, by the end of 2013, all of the Protocol signatories had released corporate social responsibility policies involving either Fair Trade or other certification programs (see Tables 3 and 4).

\section{Overview of Tables}

Tables 1 and 2 are overviews and a summary of the aspects of frame resonance utilized by all stakeholders. Upon analyzing 
Table 1 Summary of the first four components of frame resonance discussed in the study. Press releases and public statements were analyzed in order to ascertain the themes of resonance expressed in frames. These themes were then summarized

\begin{tabular}{|c|c|c|c|c|}
\hline \multicolumn{2}{|l|}{ Frame } & \multicolumn{3}{|l|}{ Resonance } \\
\hline Stakeholder/frame & Moral authority & Emotional consonance & $\begin{array}{l}\text { Engendering empathetic } \\
\text { response }\end{array}$ & Identity appeal \\
\hline $\begin{array}{l}\text { Critical Network } \\
\text { Fair Globalization }\end{array}$ & $\begin{array}{l}\text { Children's rights Human rights } \\
\text { International Conventions } \\
\text { and Treaties. } \\
\text { U.S. laws } \\
\text { Moral imperative to protect }\end{array}$ & $\begin{array}{l}\text { Guilt of consumer } \\
\text { Righteousness } \\
\text { Empowerment } \\
\text { Shaming of corporations } \\
\text { Hope Fair Trade changes } \\
\text { lives }\end{array}$ & $\begin{array}{l}\text { Interdependence of all of } \\
\text { society } \\
\text { Understanding the blight } \\
\text { of those in cocoa fields } \\
\text { Empathize with children }\end{array}$ & $\begin{array}{l}\text { Protectors for those } \\
\quad \text { who have no voice } \\
\text { Responsible consumers } \\
\text { Social conscious } \\
\text { Fair globalization }\end{array}$ \\
\hline $\begin{array}{l}\text { Fair Trade Network/ } \\
\text { Fair Trade }\end{array}$ & $\begin{array}{l}\text { Children's rights } \\
\text { Moral imperative to protect }\end{array}$ & $\begin{array}{l}\text { Guilt } \\
\text { Empowerment } \\
\text { Hope Fair Trade changes } \\
\quad \text { lives }\end{array}$ & $\begin{array}{l}\text { Interdependence of all } \\
\text { of society } \\
\text { Understanding the blight } \\
\text { of those in cocoa fields } \\
\text { Empathize with children }\end{array}$ & $\begin{array}{l}\text { Protectors for those } \\
\quad \text { who have no voice } \\
\text { Responsible consumers } \\
\text { Social conscious }\end{array}$ \\
\hline $\begin{array}{l}\text { Protocol Network/ } \\
\text { Multi-stakeholder } \\
\text { Collaboration }\end{array}$ & $\begin{array}{l}\text { Cooperation between all } \\
\text { stakeholders }\end{array}$ & $\begin{array}{l}\text { Hope Collaboration will } \\
\text { work }\end{array}$ & $\begin{array}{l}\text { Give us time to work } \\
\text { together } \\
\text { Everyone doing best }\end{array}$ & $\begin{array}{l}\text { Activists are cooperative } \\
\text { Willing to work together }\end{array}$ \\
\hline $\begin{array}{l}\text { Cocoa Industry/ } \\
\text { Responsible Cocoa } \\
\text { Sustainable }\end{array}$ & $\begin{array}{l}\text { Industry has to protect cocoa } \\
\text { market so farmers can survive }\end{array}$ & $\begin{array}{l}\text { Threat Salience Fear } \\
\text { TANS will lead to } \\
\text { downfall of economy } \\
\text { Things are getting better } \\
\text { Hope }\end{array}$ & $\begin{array}{l}\text { Corporations care } \\
\text { Working on the ground } \\
\text { collaborating } \\
\text { Empathize with companies } \\
\text { doing everything they can }\end{array}$ & $\begin{array}{l}\text { Corporations protect } \\
\text { global economy } \\
\text { Trustworthy corporations }\end{array}$ \\
\hline
\end{tabular}

Table 2 Summary of the next four components of frame resonance discussed in the study. Press releases and public statements were analyzed in order to ascertain the themes of resonance expressed in frames

\begin{tabular}{|c|c|c|c|c|}
\hline \multicolumn{2}{|l|}{ Frame } & \multicolumn{3}{|l|}{ Resonance } \\
\hline Stakeholder/frame & Empirical credibility & $\begin{array}{l}\text { Critique of other stakeholders' } \\
\text { credibility }\end{array}$ & Experiential commensurability & Narrative fidelity \\
\hline $\begin{array}{l}\text { Critical TAN/Fair } \\
\text { Globalization }\end{array}$ & $\begin{array}{l}\text { BBC and media reports } \\
\text { from ground ITTA report } \\
\text { Tulane Report } \\
\text { The Dark Side of Chocolate } \\
\text { Multi-stakeholder reports }\end{array}$ & $\begin{array}{l}\text { Corporations trying to pass } \\
\text { blame, illegal activity; IMF/ } \\
\text { World Bank need to take } \\
\text { responsibility } \\
\text { Missed Protocol deadline; not } \\
\text { making real change: some } \\
\text { making change; others still } \\
\text { holdout question } \\
\text { authenticity }\end{array}$ & $\begin{array}{l}\text { Children just like your own } \\
\text { trafficked and abused for a } \\
\text { "treat" } \\
\text { Systemic impact of corporate } \\
\text { greed and poor policies on all } \\
\text { of us. Consumer, governments } \\
\text { can change this } \\
\text { You do have power-continue } \\
\text { to watch over corporations; } \\
\text { change policies }\end{array}$ & $\begin{array}{l}\text { Corporations need to have } \\
\text { oversight and regulation } \\
\text { should have legal action } \\
\text { against them-U.S. } \\
\text { enforce laws } \\
\text { Corporate Colonialism } \\
\text { Untrustworthy } \\
\text { Corporations; } \\
\text { Corporate Accountability }\end{array}$ \\
\hline $\begin{array}{l}\text { Fair Trade TAN/ } \\
\text { Fair Trade }\end{array}$ & Same as Critical TAN & $\begin{array}{l}\text { Corporations trying to pass } \\
\text { blame, illegal activity } \\
\text { Missed Protocol deadline; not } \\
\text { making real change; some } \\
\text { making change }\end{array}$ & Same as Critical TAN & $\begin{array}{l}\text { Consumer power to make } \\
\text { change } \\
\text { Corporate Accountability }\end{array}$ \\
\hline $\begin{array}{l}\text { Protocol/ } \\
\quad \text { Multi-stakeholder } \\
\text { Collaboration }\end{array}$ & $\begin{array}{l}\text { Cooperation between } \\
\text { all stakeholders }\end{array}$ & $\begin{array}{l}\text { Cocoa companies good } \\
\text { example for other industries }\end{array}$ & $\begin{array}{l}\text { Think of times you needed } \\
\text { to compromise - can achieve } \\
\text { goals working together }\end{array}$ & $\begin{array}{l}\text { The Protocol has the } \\
\text { capacity to make real } \\
\text { changes }\end{array}$ \\
\hline $\begin{array}{l}\text { Cocoa Companies: } \\
\text { Responsible } \\
\text { Sustainable }\end{array}$ & $\begin{array}{l}\text { ITTA report-numbers } \\
\text { were exaggerated }\end{array}$ & $\begin{array}{l}\text { TANS over reactive; will } \\
\text { bring down global economy }\end{array}$ & $\begin{array}{l}\text { Global economy works. Chocolate } \\
\text { is a source of pleasure in your } \\
\text { family }\end{array}$ & $\begin{array}{l}\text { Corporations willing to } \\
\text { collaborate; working to } \\
\text { help farmers; market will } \\
\text { help farmers' profits rise; } \\
\text { company programs will } \\
\text { make real changes }\end{array}$ \\
\hline
\end{tabular}


the data in this study, it was realized that engendering an empathetic response and examining how stakeholders critiqued the other's credibility were additional aspects of resonance. Both activists and the cocoa companies used language in an effort to increase empathy for those involved in their side of the campaign. The data revealed a substantial amount of rhetoric designed to discredit and question the other stakeholder's credibility. These components were added to Maney et al.'s (2005) resonance framework.

Tables 3 and 4 outline each of the policies, the certification schemes and the frames contained within the reports. Appendix A contains the policies incorporated into the 2010 Protocol Framework.

\section{Conclusion}

Ultimately, the cocoa companies did eventually incorporate policy suggestions from the activists such as creating a transparent supply chain, increasing access to education, seeking third party certification, and increasing farmer awareness and education (see Tables 3 and 4). The policy recommendations that were not incorporated into CSR policies or the 2010 Protocol Framework were those that most challenged dominant hegemony, such as mandatory regulation and mandatory contributions to fully fund NGOs working on the ground (see Tables 3, 4, and Appendix A). UTZ and Rainforest Alliance, the first certification schemes used, prohibited forced and child labor but did not mandate a minimum price. Eventually, the signatories agreed to use Fair Trade for some, if not all of their cocoa. The Fair Trade frame was incorporated into the companies' CSRs, which may seem counterintuitive as it sets a minimum price as opposed to letting the market take over. The Critical activists have suggested that the reason for the increase in Fair Trade certification is that standards have been watered-down or that Fair Trade certification is used as a badge of legitimacy (10 Campaign 2011, and Raise the Bar Hershey! 2014).

\section{Suggestions for Social Workers}

\section{Create a Strong and Resonant Diagnostic Frame Social} workers need to make sure the diagnostic frame is based on empirical research so that solutions and the prognostic frame are incorporated into policy.

The frames espoused by the activists need to resonate with policy makers and society at large. The activists crafted a message that Fair Trade was the best way to lift cocoa farmers out of poverty. In fact, the Fair Trade suggestion was incorporated into policy recommendations from the Payson Center for International Development at Tulane University (2009-2011) as well as governmental reports (Salaam-Blyther et al. 2005) that cited information from the activists about the success of Fair Trade.

The reason the Fair Trade frame had a strong resonance is that it successfully elicited social empathy for the children in the cocoa fields while at the same time mobilized activists with a solution. Initial reports described adults and children in the cocoa fields; however, the issue became only about Worst Forms of Child Labor. The suffering of children is more likely to elicit outrage and a mobilization to action, and the activists highlighted the issues of children. The activists were instrumental in pointing out the structural inequities in the cocoa industry, contrasting the power and wealth of the companies with those of enslaved children. The activists told powerful stories of children toiling in the cocoa fields to make profits for an untrustworthy and immoral industry. Framing an issue in a way that creates empathy can create policies that lead to social justice (Segal 2011). The Fair Trade activists were successful in creating an identity of moral authority and increasing the emotional consonance of their frame in a way that resonated with stakeholders. Both the Critical and Fair Trade Network used empathy to appeal to targeted audiences.

Hold Corporations and Countries to Their Human Rights Agreements Social workers can increase the moral authority of their frame when calling on both countries and corporations to abide by their human rights agreements. The activists used the Protocol/ILO conventions as a mechanism to hold cocoa corporations accountable for their promises. Social workers can point out the myriad of U.N. treaties and conventions that countries and corporations have signed on to and call them to task to enforce those policies. This can also increase the $\mathrm{em}$ pirical credibility of the frame.

Using normative rights as the cornerstone of the narrative can "mobilizing new political allies [and] transforming institutions" (Stone 2011 p. 325). In 2002, the ILO through its International Programme on the Elimination of Child Labour (IPEC) joined the fight against child labor when it supported the creation of the International Cocoa Initiative as a part of the Protocol. Activists called on international agencies to abide by their promises and increase support, and ILO answered this call and officially created a partnership with the cocoa industry under the 2010 Framework (ILO, n.d.c).

Calling on the corporations to uphold their agreements was effective in this campaign and has also been successful in others. Hafner-Burton and Tsutsui (2005) have conceptualized that a human rights treaty may begin as "paradox of empty promises" but eventually agreements can be used "to pressure governments to change their human rights behavior" ( $p$. 1399). The same can be said for corporations; at first, a corporation may sign onto a voluntary agreement in order to pacify critics, but then activists can use the agreement "to exert leverage over corporate behavior" (McAteer and 
Table 3 Summary of Cocoa Company corporate social responsibility reports

\begin{tabular}{|c|c|c|c|c|}
\hline Cocoa Company & $\begin{array}{l}\text { ADM (Archer Daniels } \\
\text { Midland 2011) }\end{array}$ & $\begin{array}{l}\text { Blommer (Blommer } \\
\text { Chocolate Company n.d.) }\end{array}$ & $\begin{array}{l}\text { Barry Callebaut } \\
\text { (Barry Callebaut 2011) }\end{array}$ & Guittard \\
\hline Name of program & $\begin{array}{l}\text { Socially and Environmentally } \\
\text { Responsible Agriculture } \\
\text { Practices }\end{array}$ & Sustainable Origins & $\begin{array}{l}\text { Horizons } \\
\text { Cocoa-For a Better Life }\end{array}$ & A Sustainable Future \\
\hline Frames & $\begin{array}{l}\text { Collaborative Company } \\
\text { Responsible } \\
\text { Sustainable }\end{array}$ & $\begin{array}{l}\text { Collaborative Company } \\
\text { Responsible } \\
\text { Sustainable }\end{array}$ & $\begin{array}{l}\text { Child work } \\
\text { Responsible } \\
\text { Sustainable } \\
\text { Industry leader }\end{array}$ & $\begin{array}{l}\text { Collaborative Company } \\
\text { Responsible } \\
\text { Sustainable }\end{array}$ \\
\hline Programs and policies & $\begin{array}{l}\text { Community development }^{\mathrm{a}} \\
\text { Farmer training }^{\mathrm{a}} \\
\text { Clean supply chain }^{\mathrm{a}}\end{array}$ & $\begin{array}{l}\text { Community Developmen } \\
\text { Farmer training }^{\mathrm{a}}\end{array}$ & $\begin{array}{l}\text { Childhood education }^{\mathrm{a}} \\
\text { Sustainability }^{\mathrm{a}} \\
\text { Farmer training }^{\mathrm{a}} \\
\text { Cooperative development }^{\mathrm{a}}\end{array}$ & $\begin{array}{l}\text { Childhood education }^{\mathrm{a}} \\
\text { Sustainability }^{\mathrm{a}} \\
\text { Farmer training }^{\mathrm{a}}\end{array}$ \\
\hline Certification $^{\mathrm{a}}$ & $\begin{array}{l}2010 \text { UTZ certified } \\
\text { Fair Trade International }\end{array}$ & $\begin{array}{l}2009 \text { Rainforest } \\
\text { Fair Trade USA } \\
\text { Fair Trade International }\end{array}$ & $\begin{array}{l}2011 \text { UTZ } \\
\text { Fair Trade International }\end{array}$ & $\begin{array}{l}\text { Rainforest } \\
\text { Fair Trade USA }\end{array}$ \\
\hline
\end{tabular}

${ }^{\text {a }}$ Policy suggestions from activists

Pulver 2009, p. 25). Social workers should hold corporations and governments accountable to the agreements they have signed and should encourage ratification of additional treaties.

For example, social workers should also lobby for the USA to ratify the UNDR, the ICESCR, and the CRC (Reichert 2011, p. 195). Quoting Article 28 of the UNDR, social workers can advocate for the USA to assist in the creation of "international order which the rights and freedoms set forth in the Declaration can be fully realized" (Wronka 2017, p. 369).

Take Hegemony into Consideration Social workers need to also examine resonance in terms of challenging hegemony,

Table 4 Summary of Cocoa Company corporate social responsibility reports

\begin{tabular}{|c|c|c|c|c|}
\hline Cocoa Company & $\begin{array}{l}\text { Hershey } \\
\text { (Hershey 2015) }\end{array}$ & $\begin{array}{l}\text { Mars } \\
\text { (Mars 2014) }\end{array}$ & $\begin{array}{l}\text { Nestle } \\
\text { (Nestlé 2015a, b) }\end{array}$ & $\begin{array}{l}\text { World's Finest } \\
\text { (World's Finest } \\
\text { Chocolate n.d.) }\end{array}$ \\
\hline Name of program & $\begin{array}{l}\text { 21st Century Cocoa } \\
\text { Plan }\end{array}$ & Principles in Action & $\begin{array}{l}\text { Creating Shared Value-The } \\
\text { Nestlé Cocoa Plan }\end{array}$ & Rooted in Shared Success \\
\hline Frames & $\begin{array}{l}\text { Collaborative Company } \\
\text { Responsible and } \\
\text { Sustainable } \\
\text { Accountable } \\
\text { Corporate Citizen- } \\
\text { "Doing the Right } \\
\text { thing for society" }\end{array}$ & $\begin{array}{l}\text { Caring Leader } \\
\text { Sustainability through } \\
\quad \text { Science } \\
\text { Collaborative Company } \\
\text { Responsible and Sustainable } \\
\text { Corporate Global Citizen }\end{array}$ & $\begin{array}{l}\text { Sustainability } \\
\text { Collaborative Company } \\
\text { Responsible and Sustainable } \\
\text { Collaborative and } \\
\text { Responsible } \\
\text { Corporate Global Citizen }\end{array}$ & $\begin{array}{l}\text { Responsible and } \\
\text { Sustainable }\end{array}$ \\
\hline Programs and policies & $\begin{array}{l}\text { Transparent supply } \\
\text { chain }^{\mathrm{a}} \\
\text { Sustainability initiatives }^{\mathrm{a}} \\
\text { Farmer training } \\
\text { "Cocoa Link" } \\
\text { 2015-Supplier Human } \\
\text { Rights Assessment }\end{array}$ & $\begin{array}{l}\text { Transparent and clean supply } \\
\text { chain }^{\mathrm{a}} \\
\text { Farmer Training/Education }^{\mathrm{a}} \\
\text { Community development }^{\mathrm{a}} \\
\text { UN Guiding Principles on } \\
\text { Human Rights as Policy } \\
\text { Empowering Women- } \\
\text { Vision } \\
\text { for Change program }\end{array}$ & $\begin{array}{l}\text { Transparent and clean supply } \\
\text { chain }^{\mathrm{a}}\end{array}$ & $\begin{array}{l}\text { Farmer training/education } \\
\text { Childhood education }^{\mathrm{a}} \\
\text { Transparent supply chain }\end{array}$ \\
\hline Certification $^{\mathrm{a}}$ & $\begin{array}{l}2013-100 \% \text { by } 2020 \\
\text { UTZ certified } \\
\text { Fairtrade USA } \\
\text { Rainforest } \\
\text { Alliance }\end{array}$ & $\begin{array}{l}\text { 2009_UTZ certified and } \\
\text { Rainforest Alliance } \\
\text { 2011-Fairtrade USA }\end{array}$ & $\begin{array}{l}2009-\text { UTZ certified } \\
2011 \text { - FLO and Fair Labor } \\
\text { Association }\end{array}$ & $\begin{array}{l}\text { Fair Trade USA - no } \\
\text { indication how much } \\
\text { of line is certified }\end{array}$ \\
\hline
\end{tabular}

${ }^{\text {a }}$ Policy suggestions from activists 
harnessing hegemony, or a hybrid of both. A social worker's theoretical mindset will determine the manner in which (s)he frames an issue. Some social workers may feel most comfortable harnessing hegemony, using the status quo to make change and can find organizations that fit their beliefs.

Social workers that come from a critical mindset can challenge hegemony and continue to advocate for changes to neoliberal policies that have resulted in the current state of inequality found throughout our globalized world. When the frame being advocated is counter-hegemonic, as in the case of the Critical activists, the frame's resonance has to be strong in order to counter the power of prevailing ideology. This is consistent with other research that shows a frame's resonance has to be strong in order to counter elite messages found in dominant repertoire (Maney et al. 2005). The critical activists actually used prevailing hegemony as a tool to try to force the industry to make changes. They used one of the strongest tenets of capitalism, namely profits, to influence industry practices. Naming and shaming strategies are used to threaten the impact the profits of the companies. The companies that feared damage to their reputation began to make changes in their policies. Social workers should keep this in mind when advocating for change for corporations whose main goal is increasing profit.

Be Aware of Current Human Rights Campaigns The work of the activists can be then transferred to current human rights and trade campaigns including the Transpacific Partnership (TPP) and the Trans Atlantic Trade and Investment Partnership (TATIP). The TPP and TATIP can be a venue for social workers to advocate that human rights be at the core of trade agreements. Countries involved in the TPP namely, Vietnam, Mexico, Peru, and Malaysia were all named in the December 2014 "List of Goods Produced by Child Labor or Forced Labor" (Sanchez 2015, p. 51). The TPP "enables the Office of the U.S. Trade Representative to cherry-pick those countries that are most accepting of its corporate agenda, to set the rules of the game" (Stamoulis 2013 p. 31). It is a time yet again for a call to action against the corporate power grab. Social workers need to come together to advocate that human rights become the basis of the "rules of the game," above and beyond corporate profits in the TPP/TATIP.

It is important for social workers to join with activists and imagine alternatives to the present neoliberal reality that are the basis of trade agreements such as TPP/TATIP. "Every system of domination generates its own distinctive set of opportunities for challenge and transformation, and neoliberal globalization is no exception" (Evans 2008 p. 298).

Challenge the Status Quo It is crucial that not only does the power differential change but also the thought system that contributed to creating the system. Otherwise, "any movement for social justice that operates out of the dominant thoughtstructure is doomed to recreate a world that is hierarchical, that creates unequal power relationships, [and] treats certain groups and individuals as the other, who will be treated unjustly" (Brandwein 1986, p.178). It is essential for social workers to organize for human rights with "global-local alliances that do not replicate the power asymmetries of the current world order" (p. 297). In summer 2015, Pope Francis questioned this world order, calling the unfettered pursuit of money, the "dung of the devil," further stating, "once greed for money presides over the entire socioeconomic system, it ruins society, it condemns and enslaves men and women" (Huddleson 2015, para. 7).

The only way change occurs is when stakeholders work together despite ideological divides. Social workers can work with corporations and government and act as a watchdog to make sure they keep their promises secured in treaties and agreements. They can attempt to change mindsets that are embedded in a domination mentality. Fighting for human rights requires unrelenting vigilance and a commitment to change what may sometimes seem to be intractable problems. One can hope that a new narrative can create a new reality, and transforming the dominant narrative will bring about a muchneeded transformation in policy and practice.

Social workers can envision a better world and then work with other stakeholders to create that better world. Those suffering around throughout the world deserve nothing less.

\section{Compliance with Ethical Standards}

Conflict of Interest The author is a social worker who was involved in the New York State United Teachers (NYSUT) Human Rights/Fair Trade Committee. The NYSUT Human Rights/Fair Trade Committee educated students about human rights infractions in the cocoa industry and campaigned Hershey to remove child labor from the industry.

\section{References}

10 Campaign (2011). Briefing document: 10 years of unfulfilled promises to eliminate the Worst Forms of Child Labor in West Africa's Cocoa sector. Retrieved from: http://www.10campaign.com/static/faq.pdf

Abramovitz, M. (2010). Ideological perspectives and conflicts. The Dynamics of Social Welfare Policy (pp. 131-235). New York: Oxford University Press.

Agriculture, Rural Development and Food and Drug Administration's Appropriations. H.Amdt. 142, HR 2330. (2001). Retrieved from https://www.congress.gov/amendment/107th-congress/houseamendment/142/text

Agriculture, Rural Development and Food and Drug Administration's Appropriations. HR 2330. (2001). Retrieved from https://www. congress.gov/bill/107th-congress/house-bill/2330 
Archer Daniels Midland (2011). Corporate responsibility report. Retrieved from www.adm.com/en-US/responsibility/2011 $\mathrm{CR} /$ Pages/cocoa.aspx

Barnett, B. (2005). Feminist shaping news: a framing analysis of news releases from the National Organization for Women. Journal of Public Relations Research, 17(4), 341-362.

Barry Callebaut (2011). Corporate responsibility and sustainability 2011/12 Retrieved from https://www.barrycallebaut. com/system/files/download/barry_callebaut_csr_report_2011-12_e.pdf

BBC News (2001 April 12). Mali's children in chocolate slavery, Retrieved from http://news.bbc.co.uk/2/hi/africa/1272522.stm

Benford, R. D., \& Snow, D. A. (2000). Framing processes and social movements: an overview and assessment. Annual Review Sociology, 26, 611-639.

Blommer Chocolate Company (n.d). Sustainability programs. Retrieved from www.bloomer.com

Brandwein, R. A. (1986). Feminist thought-structure: an alternative paradigm of social change for social justice toward social and economic justice. Cambridge: Schenkman Publishers.

Chatterjee, S. \& Raghavan, S. (2001, June 25). A taste of slavery. Knight Ridder Newspapers, Retrieved from http://vision.ucsd. edu/ kbranson/stopchocolateslavery/atasteofslavery.html

CNN Freedom Project (2012 January 19). Chocolate's child slaves. Retrieved from: http://thecnnfreedomproject.blogs.cnn.com/2012 /01/19/child-slavery-and-chocolate-all-too-easy-to-find/

Coburn, C. E. (2006). Framing the problem of reading instruction: using frame analysis to uncover the microprocesses of policy implementation. American Educational Research Journal, 43(3), 343-379.

Committee on Social Work Education (2008). Educational policies and accreditation standards. Retrieved from: http://www.cswe. org/Accreditation/2008EPASDescription.aspx

Dadson, A. (2001 May 4). Farmers need higher cocoa prices [Press Release] Retrieved from www.prnewswire.com

Dahan, N. M., \& Gittens, M. (2010). Business and the public affairs of slavery: a discursive approach of an ethical public issue. Journal of Business Ethics, 92, 227-249. doi:10.1007/s10551009-0151-8.

Engel, E. (2001). Congressman Eliot Engel 107th Congress press release. Retrieved from https://engel.house.gov/107th-congress-pressreleases/engel-hails-creation-of-international-foundation-to-fightchild-slavery-in-cocoa-production/

Etzioni, A. (2010). The normativity of human rights is self-evident. Human Rights Quarterly, 32, 187-197.

Evans, P. (2008). Is an alternative globalization possible? Politics \& Society, 36(2), 271-305. doi:10.1177/0032329208316570.

Free the Slaves (n.d.). Global advocacy. Retrieved from: http://www. freetheslaves.net/global-advocacy/policy-advocacy/

Gillan, K. (2008). Understanding meaning in movements: a hermeneutic approach to frames and ideologies. Social Movement Studies, 7(3), 247-263.

Global Exchange (2002). Over 200 religious, labor, and human rights groups calls on M\&M/Mars to offer Fair Trade chocolate. Retrieved from: http://www.globalexchange.org/news/over-200religious-labor-and-human-rights-groups-calls-mmmars-offer-fairtrade-chocolate

Grossman-Greene, S., \& Bayer, C. (2009). A History of child labor child rights \& the Harkin Engel Protocol: Tulane University-Payson Center for International Development.

Hafner-Burton, E. M., \& Tsutsui, K. (2005). Human rights in a globalizing world: the paradox of empty promises. American Journal of Sociology, 110(5), 1373-1411.

Harkin-Engel Protocol (2001). Retrieved from http://harkin.senate. gov/documents/pdf/HarkinEngelProtocol.pdf

Hershey (2013). Shared Goodness Cocoa Certification [Press release] http://www.thehersheycompany.com/social-responsibility/sharedgoodness
Hershey (2015). 2014 Corporate social responsibility report. Retrieved from http://www.thehersheycompany.com/socialresponsibility/shared-goodness

Huddleson,T. (2015, September 14). 5 times Pope Francis talked about money. Fortune. Retrieved from: http://fortune.com/2015/09/14 /pope-francis-capitalism-inequality/

ILO (n.d.) About the ILO. Retreived from: http://www.ilo. org/global/about-the-ilo/lang-en/index.htm. Accessed 3 Oct 2016.

International Council on Social Welfare ICSW (2012). Global agenda: Social work and social development. Retrieved from http://ifsw. org/get-involved/agenda-for-social-work/

International Federation of Social Workers IFSW (n.d.). Statement of principals. Retrieved from: http://ifsw.org/policies/statement-ofethical-principles/

International Labor Organization (n.d.a). Forced Labor Convention. Retrieved from: http://www.ilo.org/dyn/normlex/en/f?p= NORMLEXPUB:12100:0::NO::P12100 ILO CODE:C029

International Labor Organization (n.d.b.). Abolition of Forced Labour. Retrieved from: http://www.ilo.org/dyn/normlex/en/f?p= NORMLEXPUB:12100:0::NO::P12100_ILO CODE:C105

International Labor Organization (n.d.c). Forced Labor Convention. Retrieved from: https://business.un.org/en/documents/10982

International Labor Rights Forum (2002). Statement on industry Protocol regarding the use of child labor in West African cocoa farms [Press Release]. Retrieved from http://www.laborrights. org/sites/default/files/publications-and-resources/

International Labor Rights Forum (2004). The World Bank and IMF policies in Côte d'Ivoire: Impact on the child labor in the cocoa industry. Retrieved from: http://www.laborrights. org/sites/default/files/publications-and-resources/COCOAWBIMF.pdf

International Labor Rights Forum (n.d) ILRF continues to reshape the field of labor rights by advancing innovative policies and laws that protect workers. Retrieved from http://www.laborrights. org/strategies/trade-justice-0

Jeffery, S., \& Stafford, B. (2001 April). Slavery: the chocolate companies have their say. The Guardian. Retrieved from: http://www. theguardian.com/world/2001/apr/19/globalisation.benstafford

Maney, G. M., Coy, P. G., \& Woehrle, L. M. (2005). Framing policy after 9/11: Hegemony, resonance and resistance. Paper presented at the annual meeting of the American Sociological Association.

Mars (2012) Mars principles in action. Retrieved from: http://www.mars. com/global/about-mars/mars-pia/our-supply-chain/cocoa.aspx

Mars (2014). Mars principles in action. Retrieved from: http://www.mars. com/global/about-mars/principles-in-action.aspx.

McAteer, E., \& Pulver, S. (2009). The corporate boomerang: shareholder transnational advocacy networks targeting oil companies in the Ecuadorian Amazon. Global Environmental Politics, 9(1), $1-30$.

National Confectioners Association Chocolate Council (2012, April 4) Expansion of industry programs to improve the lives of cocoa farming communities in Côte and Ghana. Retrieved from www. candyusa.com

Nestlé (2010). Rural development report. Retrieved from: http://www. nestle.com/asset-library/Documents/Library/Documents/Corporate Social Responsibility/2010

Nestlé (2015a). The Nestlé cocoa plan. Retrieved from: http://www. nestle.com/csv/rural-development-responsible-sourcing/nestlecocoa-plan

Nestlé (2015b). Nestlé Action Plan on Women in the Cocoa Supply Chain. Retrieved from http://www.nestle.com/media/news/coteivoire-women-cocoa

Nieburg, (2011, November 30). Nestle 'sure' child labour occurs in supply chain as company allows probe. Confectionary News. Retrieved from: http://www.confectionerynews.com/Regulation- 
Safety/Nestle-sure-child-labour-occurs-in-supply-chain-ascompany-allows-probe.

Off, C. (2006). Bitter chocolate: anatomy of an industry. New York: The New Press.

Onishi, N. (2001 July 29). The bondage of poverty that produces chocolate, The New York Times. Retrieved from http://www.nytimes.com

Parkhurst, J. (2012). Framing, ideology and evidence: Uganda's HIV success and the development of PEPFAR's ABC policy for HIV Prevention. The Policy Press, 8(1), 17-36.

Payson Center for International Development and Technology Transfer at Tulane University (2009-2011). Survey research on child labor in West African cocoa growing areas. Retrieved from: http://www. payson.tulane.edu/projects/survey-research-child-labor-westafrican-cocoa-growing-areas\#sthash.AXUROoep.dpuf

Pyles, L. (2009). Where's the "freedom" in Free Trade? Framing practices and global economic justice. Journal of Community Practice, 17, 73-87. doi:10.1080/10705420902856183.

Raise the Bar, Hershey! Campaign (2014, March 14.). Hershey and Barry Callebaut lag industry in addressing child labor. Retrieved from http://www.globalexchange.org/news/hershey-and-barry-callebautlag-industry-addressing-child-labor

Reichert, E. (2011). Human rights in social work: an essential basis. Journal of Comparative Social Welfare. (27) 3.

Risse, T., Ropp, S. C., \& Sikkink, K. (Eds.). (1999). The power of human rights: international norms and domestic change. Cambridge: Cambridge University Press.

Salaam-Blyther, T., Hanrahan, C., \& Cook, N. (2005) Child labor in West African cocoa production: Issues and U.S. policy-.CRS Report for Congress.

Sanchez, L. (2015).When it comes to free trade policy, human rights should be a game changer. Harvard Journal on Legislation (52).

Sandberg, S. (2006). Fighting neo-liberalism with neo-liberal discourse: ATTAC Norway, Foucault and collective action framing. Social Movement Studies, 5(3), 209-227. doi:10.1080/14742830600991529.

Segal. (2011). Social empathy: a model built on empathy, contextual understanding, and social responsibility that promotes social justice. Journal of Social Service Research, 37, 266277.

Snow, D. A., \& Benford, R. D. (1988). Ideology, frame, resonance, and participant mobilization. International Social Movement Research, $1,197-218$.

Snow, D., \& Benford, R. (2005). Clarifying the relationship between framing and ideology. In: H. Johnston \& J. A. Noakes (Eds.), Frames of protest: Social movements and theframing perspective (pp. 205-212): Rowman \& Littlefield.

Stamoulis, A. (2013). Trading away the future: an analysis of the Trans-Pacific Partnership. New Labor Forum, 22(3), 30-37. doi:10.1177/1095796013498856nlf.sagepub.com.

Stone, D. (2011). Policy paradox: the art of political decision-making. New York: W. W. Norton \& Company.

Toler, D., \& Schweisguth, M. (2003). While chocolate lovers smile, child cocoa workers cry: Abusive child labor in the cocoa industry: How corporations and international financial institutions are causing it, and how Fair Trade can solve it. Global Exchange Report. Retrieved from: http://www.globalexchange.org/sites/default/files/cocoareport2003. pdf

Toynbee, P. (2009). Wall Street wounded Ghana. IMF tonic could hurt more. The Guardian. Retrieved from guardian.co.uk.

United Nations (1994). Human rights and social work: a manual for schools of social work and the social work profession.

United Nations Human Rights Office of the High Commissioner (n.d.a). United Nations Rights by Country. Retrieved from:http://tbinternet. ohchr.org/_layouts/TreatyBodyExternal/Treaty.aspx?CountryID $=42$ \&Lang=EN

United Nations Human Rights Office of the High Commissioner (n.d.b). Convention on the Rights of the Child. Retrieved from: http://www. ohchr.org/en/professionalinterest/pages/crc.aspx

World's Finest Chocolate (n.d). World's finest chocolate: discover the best. Retrieved from www.worldsfinestchocolate.com

Wronka, J. (2017). Human rights and social justice: social action and service for the helping and health professionals. Los Angeles: Sage Publishing. 